\begin{tabular}{l|l}
\hline Notaice & e-ISSN: $2655-9404$ \\
Vol. 01 No. 1, Juni 2018 & DOI: $10.20473 /$ ntr.v1i1.9103 \\
\hline
\end{tabular}

Article history: Submitted 1 May 2018; Accepted 15 May 2018; Available online 1 June 2018.

\title{
Perjanjian Lisensi Dalam Penggunaan Musik Sampling
}

\author{
Septiani Ayu Rizkiyana \\ septianiayur@gmail.com \\ Universitas Airlangga
}

\begin{abstract}
Music is one of work that is protected under copyright. With the development of technology, there are many developments in music techniques that used by the musicians, which one of them is music sampling. Sampling is done by taking part of the composition or recorded song or music that has been there, that part then processed and combined with the composition created by the sampler itself, produce a brand new song or music. The results of the use of sampling can be protected by a separate copyright from the origin song or music as original work. But in the use of sampling required permission either from the creator and / or related rights owner of the origin song or music to avoid copyright infringement. the permission shall state in written form either authentic deed made by notary or privately made deed. The license agreement is then registered so it will have a legal effect against the third party.
\end{abstract}

Keywords: Music; Copyright and Related Right; Licensing Agreement.

\begin{abstract}
Abstrak
Musik merupakan salah satu ciptaan yang dilindungi dalam hak cipta. Seiring dengan perkembangan teknologi, terdapat pula banyak perkembangan teknik dalam bermusik yang dilakukan oleh musisimusisi, salah satunya adalah musik sampling. Sampling dilakukan dengan mengambil bagian dari komposisi atau rekaman lagu atau musik yang telah ada, bagian tersebut kemudian diolah dan dikombinasikan dengan komposisi yang dibuat oleh sampler sendiri, sehingga menghasilkan lagu atau musik yang baru. Hasil dari penggunaan sampling ini dapat dilindungi dengan hak cipta sebagai ciptaan asli terpisah dari lagu atau musik asal. Akan tetapi dalam penggunaan musik sampling dibutuhkan izin baik dari pencipta dan/atau pemilik hak terkait dari lagu atau musik asal agar tidak terjadi pelanggaran hak cipta. Izin yang diberikan dituangkan dalam bentuk perjanjian lisensi secara tertulis baik berupa akta otentik yang dibuat oleh notaris maupun akta di bawah tangan. Perjanjian lisensi kemudian perlu dilakukan pendaftaran agar memiliki akibat hukum terhadap pihak ketiga.

Kata Kunci: Musik; Hak Cipta dan Hak Terkait; Perjanjian Lisensi.
\end{abstract}

\section{Pendahuluan}

Musik merupakan hasil kreatifitas manusia dalam bentuk harmonisasi bunyi yang terbentuk dari adanya irama, melodi, dan vokal. Pada era modern ini, musik mengalami perkembangan baik genre, alat-alat musik, teknologi dan teknik dalam bermusik. Salah satu perkembangan dalam Periode ini adalah Sampling. Definisi dari Sampling adalah proses yang dilakukan musisi atau produser fonogram dengan mengambil potongan suara atau beberapa bagian dari suatu komposisi atau 
rekaman musik lain dan menggunakan bagian tersebut dalam suatu komposisi yang baru. ${ }^{1}$ Konsep dari Sampling bermula ketika Jamaika mendapatkan kemerdekaan dari Jajahan Inggris pada tahun 1962 yang lebih dikenal dengan sebutan riddim. ${ }^{2}$ Setelah mendapatkan kepopuleran di Jamaika, pada tahun 1974, Riddim mulai diperkenalkan di Amerika Serikat dengan adanya penyesuaian dengan budaya Amerika Serikat. Teknik Riddim inipun diadaptasi oleh masyarakat Amerika dan akhirnya menjadi cikal bakal dari musik hip hop dan rap di Amerika. ${ }^{3}$ Seiring dengan perkembangan musik tidak hanya digunakan dalam musik hip hop dan rap, akan tetapi digunakan juga pada musik pop, funk, dance, house, techno, trip-hop dan acid jazz. ${ }^{4}$

Perkembangan musik seperti yang telah dijelaskan sebelumnya, tidak dapat terlepas dari perkembangan kehidupan manusia. Dengan adanya perkembangan jaman dan teknologi, musik yang pada awalnya hanya dianggap sebagai perwujudan ekspresi dari penciptanya, mulai dianggap memiliki nilai ekonomi dengan dilakukannya produksi musik dalam bentuk rekaman dan dijual secara masal di pasar baik dalam kemasan kaset, Compact Disc ${ }^{5}$ atau yang dijual secara digital melalui sistem online. Keuntungan dari industri musik ini tidak hanya berdampak pada individu atau perusahaan musik, tetapi juga pada Negara.

Sebagai suatu bentuk hasil karya dari manusia, musik merupakan salah satu ciptaan yang dilindungi dalam Hak Kekayaan Intelektual. HKI pertama kali dikemukakan pada masa Abad keempat sebelum masehi dengan landasan filosofis untuk memberikan penghargaan bagi pencipta atau penemu atas kreasi intelektual yang berguna bagi masyarakat. ${ }^{6}$ Dengan adanya penghargaan terhadap pencipta atau penemu tersebut, dapat dikatakan bahwaHKImerupakan hak yang bersifat pribadimilik pencipta tersebut, sehingga dengan adanya penghargaan terhadap kreasi intelektual

\footnotetext{
${ }^{1}$ Brian Fitzgerald, [et., al.], 'Digital Sampling And Culture Jamming In A Remix World: What Does The Law Allow?', (2005), 10(4) Media and Arts Law Review, [3].

${ }^{2}$ Henry Self, 'Digital Sampling (A Cultural Perpective)', (2002), 9:2 UCLA Entertainment Law Review, [348].

${ }^{3}$ ibid, [349-351].

${ }^{4}$ Brian Fitzgerald, [et.,al.], Op. Cit., [4].

${ }^{5}$ Piringan yang digunakan untuk merekam karya musik dalam sistem digital.

${ }^{6}$ Rahmi Jened, Interface Hukum Kekayaan Intelektual dan Hukum Persaingan (Penyalahgunaan HKI) (Rajawali Press 2013).[23].
} 
tersebut diharapkan dapat memberikan motivasi untuk melakukan pengembangan dan penemuan kreasi baik dalam bentuk inovasi, teknologi, ilmu pengetahuan, dan kesenian yang dapat berguna bagi masyarakat. HKI secara garis besar dibagi menjadi dua bagian, yaitu Hak Cipta dan Hak terkait Hak Cipta (Copyright and Related Right) dan Hak Kekayaan Industri (Industrial Property Right). Berdasarkan Pasal 2 Berne Convention for the Protection of Literary and Artistic Works, Objek dari Hak Cipta meliputi karya-karya sastra, ilmiah, dan seni dalam bentuk media apapun. Berdasarkan penjelasan mengenai objek hak cipta tersebut dapat disebutkan bahwa musik merupakan karya yang dilindungi oleh Hak Cipta.

Berdasarkan sistem hukum yang dianut oleh suatu Negara, terdapat dua bentuk pendekatan hak cipta, yaitu berdasarkan Common law system dan Civil law system. Pada Negara Common law system, hak cipta dikenal dengan konteks copyright system atau right to copy atau hak untuk memperbanyak Ciptaan yang bertitik tolak perlindungannya pada ciptaannya. ${ }^{7}$ Penekanan pada perlindungan terhadap ciptaan dalam common law system, menyebabkan pengertian pencipta dalam konteks ini dapat berupa individu maupun badan hukum. ${ }^{8}$ Sedangkan pada Civil law system mengenal konteks author right yang bertitik tolak perlindungannya pada penciptanya. ${ }^{9}$ Dalam civil law system, hak cipta merupakan wujud dari kepribadian dari penciptanya, sehingga pencipta dalam konteks ini adalah hanya manusia dan badan hukum tidak dapat disebut pencipta selayaknya di common law system.

Salah satu contoh Negara common law system adalah Amerika Serikat. Sebagai Negara tempat berkembangnya Sampling, banyak musisi yang menggunakan sampling sebagai proses yang dilakukan saat menciptakan suatu karya musik. Adanya nilai ekonomi dari karya musik tersebut, muncul beberapa gugatan mengenai penggunaan sampling. Misalnya pada kasus “Newton v Diamond" pada tahun 2002, sebuah band dengan genre rock dan hip-hop, The Beastie Boys melakukan sampling terhadap enam detik dan tiga not dari komposisi flute yang komposisi musik dan penampilannya

\footnotetext{
${ }^{7}$ ibid.[74].

${ }^{8}$ Simon Stokes, Art \& Copyright (Hart Publishing 2001).[4].

${ }^{9}$ Rahmi Jened, Loc. Cit.
} 
dilakukan oleh James W. Newton, Jr.. Newton menggugat The Beastie Boys karena dianggap telah melanggar hak cipta dari komposisi musik yang telah dia buat.

Kemudian pada tahun 2004, terdapat kasus mengenai sampling lainnya yaitu "Bridgeport Music Inc v Dimension Films". Pihak penggugat dalam kasus ini adalah Bridgeport dan Southfield yang bergerak di bidang penerbit komposisi musik dan Westbound Records dan Nine Records yang bergerak di bidang rekaman dan distribusi rekaman suara dengan tergugat No Limits Film dan Dimension Films. Dasar dari gugatan ini adalah adanya penggunaan sampling dari komposisi dan rekaman suara dari lagu Get Off Your Ass and Jam (Get Off) milik Funkadelic yang dilakukan oleh grup rap N.W.A dalam lagunya yang berjudul 100 Miles and Runnin (100 Miles) yang merupakan salah satu soundtrack dari film I Got the Hook Up yang dianggap oleh penggugat melanggar hak cipta karena tidak melakukan lisensi terhadap pihak penggugat.

Indonesia sendiri merupakan salah satu negara civil law system, sehingga hak cipta yang dikenal adalah author right yang bertitik tolak pada pencipta. Musik di pasar Indonesia dapat dikatakan merupakan musik yang mengikuti tren di masyarakat dan tak jarang juga mengikuti tren musik dari negara lain. Sehingga dengan berkembangnya industri musik baik di luar maupun dalam negeri, pengetahuan hukum yang berkaitan dengan musik yaitu mengenai hak cipta dan hak terkait serta perjanjiannya perlu ikut berkembang.

Berdasarkan latar belakang tersebut, maka yang akan dikaji dalam tulisan ini adalah sebagai berikut:

1. Apakah hasil dari penggunaan musik Sampling dapat dilindungi sebagai hak cipta?

2. Bagaimana bentuk lisensi dalam perjanjian lisensi mengenai penggunaan musik Sampling?

Penelitian yang dilakukan dalam penulisan ini adalah penelitian hukum. menurut Morris L. Cohen, Legal Research is the process of finding the law that 
governs activities in human society. ${ }^{10}$ Bila pengertian dari Cohen tersebut dikaitkan dengan ilmu hukum yang merupakan ilmu yang bersifat terapan dan preskriptif dimana objek dari ilmu hukum adalah koherensi dari tingkah laku (act) individu dengan norma hukum, ${ }^{11}$ maka penelitian hukum adalah penelitian yang memiliki tujuan untuk menjawab isu-isu hukum yang terdapat didalam masyarakat sehingga diharapkan hasil dari penelitian hukum yang dilakukan oleh penulis dapat berdampak positif dan dapat diterapkan ke dalam masyarakat. Pendekatan yang akan digunakan dalam penulisan kajian ini adalah pendekatan Perundang-undangan (Statue Approach) dan Pendekatan Konseptual (Conceptual Approach).

\section{Pengaturan Hak Cipta di Indonesia}

Hak cipta di Indonesia saat ini diatur dalam Undang-Undang Nomor 28 tahun 2014 tentang Hak Cipta (selanjutnya akan disebut sebagai UU Hak Cipta). Undangundang ini merupakan pengganti dari Undang-Undang nomor 19 tahun 2002 yang telah dicabut dan dinyatakan tidak berlaku pada saat Undang-Undang Nomor 28 tahun 2014 diundangkan. Hak Cipta adalah hak eksklusif pencipta yang timbul secara otomatis berdasarkan prinsip deklaratif setelah suatu ciptaan diwujudkan dalam bentuk nyata tanpa mengurangi pembatasan sesuai dengan ketentuan peraturan perundang-undangan. ${ }^{12}$ Berdasarkan pengertian hak cipta tersebut, dapat diuraikan bahwa terdapat tiga unsur dalam hak cipta, yaitu adanya pencipta, adanya ciptaan, dan adanya hak eksklusif.

\subsection{Pencipta dalam hak cipta}

Sebagai Negara yang menganut civil law system, Indonesia menekankan perlindungan hak cipta pada pencipta dari ciptaan tersebut. Dalam Pasal 1 angka 2 UU Hak Cipta, Pencipta itu sendiri dijelaskan sebagai seorang atau beberapa orang yang secara sendiri-sendiri atau bersama-sama menghasilkan suatu ciptaan

\footnotetext{
${ }^{10}$ Peter Mahmud Marzuki, Penelitian Hukum (Prenadamedia Group 2011).[58].

${ }^{11}$ ibid.[41].

${ }^{12}$ Pasal 1 angka 1 UU Hak Cipta.
} 
yang bersifat khas dan pribadi. Pencipta dalam hal ini merupakan natural person, ${ }^{13}$ sehingga diharapkan ciptaan yang tercipta merupakan hasil akal budi dari manusia. Berdasarkan Pasal 31 UU Hak Cipta, yang dianggap sebagai Pencipta, yaitu Orang yang namanya:

1. disebut dalam Ciptaan; istepi

2. dinyatakan sebagai Pencipta pada suatu Ciptaan; isẹp:

3. disebutkan dalam surat pencatatan Ciptaan; dan/atau istepi

4. tercantum dalam daftar umum Ciptaan sebagai Pencipta. istepi

Ketika seseorang yang terlibat dalam penciptaan ciptaan tersebut lebih dari satu orang, maka berdasarkan Pasal 33 UU Hak Cipta menyatakan bahwa yang dianggap sebagai pencipta adalah orang yang memimpin dan mengawasi penyelesaian seluruh ciptaan. Kemudian ketika dalam penciptaan tersebut tidak ada yang memimpin dan mengawasi penyelesaian, maka yang akan dianggap sebagai pencipta adalah Orang yang menghimpun Ciptaan dengan tidak mengurangi Hak Cipta masing-masing atas bagian Ciptaannya.

1.2. Ciptaan dalam hak cipta

Berdasarkan Pasal 1 angka 3 UU Hak Cipta, Ciptaan adalah setiap hasil karya cipta di bidang ilmu pengetahuan, seni, dan sastra yang dihasilkan atas inspirasi, kemampuan, pikiran, imajinasi, kecekatan, keterampilan, atau keahlian yang diekspresikan dalam bentuk nyata. Ciptaan yang dapat dilindungi merupakan milik pribadi dari pencipta, bukan merupakan milik umum (public domain). Hal ini berkaitan dengan penekanan perlindungan pencipta pada hak cipta dalam civil law system, maka ciptaan tersebut merupakan perwujudan dari ekspresi pribadi pencipta. Sehingga melihat pengertian dari ciptaan dalam UU Hak Cipta tersebut, ciptaan baru dapat dikatakan dilindungi hak cipta ketika ciptaan tersebut telah diekspresikan dalam bentuk konkret.

Pasal 2 Berne Convention mengatur mengenai ciptaan-ciptaan yang dapat dilindungi oleh hak cipta yang pada dasarnya membagi ciptaan dalam dua kelompok, yaitu Ciptaan asli dan Ciptaan turunan. Ciptaan asli yang dimaksud

${ }^{13}$ Natural person atau dalam bahasa Indonesia disebut manusia merupakan salah satu dari subjek hukum selain legal person atau badan hukum. 
dalam Berne Convention adalah ekspresi dari karya sastra dan seni baik dalam bidang ilmu pengetahuan, seni, dan sastra. Konsep ciptaan asli ini tidak terlepas dari teori hukum dalam Hak Cipta mengenai standar perlindungan hak cipta yaitu Originality, Creativity, dan Fixation. ${ }^{14}$

Persyaratan Originality adalah bagaimana manusia sebagai makhluk yang berakal menuangkan ide dan pemikirannya dalam sebuah bentuk khusus. ${ }^{15}$ Persyaratan Creativity dalam Hak Cipta terkait dengan adanya kreasi intelektual pribadi yang artinya suatu Ciptaan tersebut merupakan hasil karya, karsa, dan rasa manusia. ${ }^{16}$ Berdasarkan penjelasan tersebut, maka tingkat kreativitas dari suatu ciptaan akan dinilai dari bagaimana pencipta menggunakan keterampilan dan keahliannya sendiri sebagai manusia, bukan berasal dari teknologi atau binatang. Kemudian untuk persyaratan Fixation merupakan konsep bentuk material dari ciptaan yang akan dilindungi oleh Hak Cipta. ${ }^{17}$ Seperti dijelaskan dalam pengertian Ciptaan, bahwa Ciptaan baru akan dilindungi oleh Hak Cipta ketika ciptaan tersebut diwujudkan dalam bentuk nyata, sehingga sebuah ide dan pemikiran tidak bisa disebut sebagai ciptaan yang dilindungi hak cipta. Ketika ketiga persyaratan tersebut sudah dipenuhi dalam sebuah ciptaan, maka ciptaan tersebut dapat dikatakan sebagai ciptaan asli dalam Hak Cipta.

Dalam Pasal 2 ayat 3 Berne Convention diatur mengenai ciptaan turunan yang menjelaskan bahwa ciptaan turunan merupakan terjemahan, adaptasi, arasemen musik dan bentuk lainnya dari karya sastra dan seni yang didasarkan pada sebuah ciptaan yang sudah ada yang tetap dilindungi secara terpisah dari karya aslinya. Contoh dari ciptaan turunan ini adalah adaptasi cerita novel yang dibuat menjadi sebuah film, naskah terjemahan, atau arasemen lagu. Berdasarkan ketentuan tersebut, maka ciptaan turunan memiliki perlindungan hak cipta secara mandiri dan terpisah dari ciptaan asli yang merupakan inspirasi awal dari ciptaan turunan tersebut.

\footnotetext{
${ }^{14}$ Rahmi Jened, Loc. Cit.[79].

${ }^{15}$ ibid. [81].

${ }^{16}$ ibid.

${ }^{17}$ ibid. [84].
} 


\subsection{Hak eksklusif dalam hak cipta}

Berdasarkan Pasal 4 UU Hak Cipta, hak ekslusif dari hak cipta terdiri atas hak moral dan hak ekonomi. Hak moral merupakan hak yang melekat pada diri pencipta dan tidak dapat dialihkan kepada siapapun selama pencipta masih hidup, akan tetapi pelaksanaan dari hak tersebut masih dapat dilaksanakan dengan berdasarkan wasiat atau sebab lain sesuai ketentuan perundang-undangan setelah pencipta meninggal dunia. Berdasarkan Pasal 5 ayat 1 UU Hak Cipta, hak moral merupakan hak dari pencipta untuk:

a. tetap mencantumkan atau tidak mencantumkan namanya pada salinan sehubungan dengan pemakaian Ciptaannya untuk umum; isep

b. menggunakan nama aliasnya atau samarannya; [š

c. mengubah Ciptaannya sesuai dengan kepatutan dalam masyarakat; istepe:

d. mengubah judul dan anak judul Ciptaan; dan șép.

e. mempertahankan haknya dalam hal terjadi distorsi Ciptaan, mutilasi Ciptaan, modifikasi Ciptaan, atau hal yang bersifat merugikan kehormatan diri atau

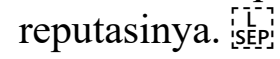

Berdasarkan hak-hak moral diatas, dapat dikatakan bahwa hak moral merupakan hak pribadi dari pencipta dan pencipta diberikan kebebasan oleh Undang-undang untuk melakukan apapun terhadap ciptaannya. Apabila terdapat pelanggaran terhadap hak moral dari pencipta tersebut yang dianggap telah merugikan kepentingan pencipta, maka baik pencipta atau ahli warisnya dapat menggugat pelanggaran tersebut ke pengadilan niaga.

Selain hak moral, dalam hak cipta juga terdapat hak ekonomi, yaitu hak untuk mendapatkan manfaat dari ciptaan. Berdasarkan Pasal 9 ayat 1 UU Hak Cipta, Hak ekonomi merupakan hak bagi pencipta atau pemegang hak cipta untuk melakukan:

a. Penerbitan Ciptaan;

b. Penggandaan Ciptaan dalam segala bentuknya;

c. Penerjemahan Ciptaan;

d. Pengadaptasian, pengaransemenan, atau pentransformasian Ciptaan; istepi

e. Pendistribusian Ciptaan atau salinannya; [istep]

f. Pertunjukan Ciptaan; ;LẸp]

g. Pengumuman Ciptaan; istepi

h. Komunikasi Ciptaan; dan išpep

i. Penyewaan Ciptaan. [s- 
Berbeda dengan hak moral yang melekat dan hanya dapat dinikmati oleh pencipta, hak ekonomi tidak hanya terbatas dimiliki oleh pencipta, akan tetapi juga pemegang hak cipta. Berdasarkan Pasal 1 angka 4 UU Hak Cipta, Pemegang Hak Cipta adalah Pencipta sebagai pemilik Hak Cipta, pihak yang menerima hak tersebut secara sah dari Pencipta, atau pihak lain yang menerima lebih lanjut hak dari pihak yang menerima hak tersebutsecara sah.š hak cipta memiliki pengertian yang lebih luas, tidak hanya terbatas pada pencipta akan tetapi kepada kepada orang lain selain pencipta yang secara sah mendapatkan peralihan hak cipta dari pencipta. Selain itu, Negara dapat pula menjadi pemegang hak cipta, yaitu menjadi pemegang hak cipta atas ekspresi budaya tradisional dan terhadap Ciptaan yang tidak diketahui Penciptanya baik ciptaan tersebut belum diterbitkan atau sudah diterbitkan akan tetapi tidak diketahui juga penerbitnya. Dipegangnya hak cipta terhadap ciptaan yang tidak diketahui penciptanya oleh Negara dilakukan untuk melindungi kepentingan dari pencipta.

Untuk dapat menjadi pemegang hak cipta, maka seseorang tersebut harus mendapatkan peralihan hak cipta secara sah. hak cipta itu sendiri dapat dikatakan sebagai benda bergerak tidak berwujud yang dapat beralih atau dialihkan baik sebagian atau seluruhnya kepada orang lain karena pewarisan, hibah, wakaf, wasiat, perjanjian tertulis, dan sebab lain yang dibenarkan sesuai dengan ketentuan peraturan perundangundangan. ${ }^{18}$ Akan tetapi walaupun hak cipta dapat dialihkan, terdapat ciptaan yang walaupun telah dialihkan dengan perjanjian jual putus dan/atau pengalihan tanpa batas waktu, ketika hak cipta yang telah dialihkan tersebut sudah melampaui jangka waktu 25 tahun, hak cipta yang telah dialihkan tersebut akan kembali kepada pencipta atau ahli warisnya. Hal ini berlaku terhadap ciptaan buku dan/atau semua hasil karya tulis lainnya, lagu atau musik dengan atau tanpa teks.

Setelah terpenuhinya unsur-unsur yang menunjukkan seseorang memperoleh hak cipta, maka secara otomatis ciptaan tersebut akan dilindungi selama jangka waktu tertentu. Untuk perlindungan hak moral pencipta, UU

\footnotetext{
${ }^{18}$ Pasal 16 UU Hak Cipta.
} 
Hak Cipta membedakan jangka waktu perlindungan berdasarkan jenis hak yang dimiliki oleh pencipta. Terhadap hak moral pencipta untuk tetap mencantumkan atau tidak mencantumkan namanya pada salinan sehubungan dengan pemakaian Ciptaannya untuk umum; menggunakan nama aliasnya atau samarannya; isepidan mempertahankan haknya dalam hal terjadi distorsi Ciptaan, mutilasi Ciptaan, modifikasi Ciptaan, atau hal yang bersifat merugikan kehormatan diri atau reputasinya, UU Hak Cipta memberikan perlindungan tanpa batas waktu. Sedangkan terhadap hak moral pencipta untuk mengubah Ciptaannya sesuai dengan kepatutan dalam masyarakat; dan mengubah judul dan anak judul Ciptaan, UU Hak Cipta memberikan perlindungan selama berlangsungnya jangka waktu Hak Cipta atas Ciptaan yang bersangkutan.

Selain hak moral, hak ekonomi dalam hak cipta juga dilindungi dalam jangka waktu tertentu. Dalam UU Hak Cipta, perlindungan hak cipta yang diatur dalam Pasal 58 sampai dengan Pasal 61 dapat dibedakan berdasarkan jangka waktu perlindungannya, yaitu:

1) Ciptaan yang dilindungi selama hidup Pencipta ditambah 70 tahun;

2) Ciptaan yang dilindungi selama 50 tahun sejak pertama kali dilakukannya pengumuman;

3) Ciptaan yang dilindungi selama 25 tahun sejak pertama kali dilakukan pengumuman; dan

4) Ciptaan yang dilindungi tanpa batas waktu.

Dalam pembuatan suatu ciptaan, tidak menutup kemungkinan bahwa ciptaan tersebut secara utuh diumumkan. Ada kalanya, pengumuman atas suatu ciptaan dilakukan bagian per bagian atau per jilid. Berhubungan dengan masa berlaku ciptaan tersebut, dalam UU Hak Cipta diatur pula mengenai penentuan masa berlaku ciptaan yang diumumkan secara berkala. Berdasarkan Ciptaan yang dilakukan Pengumuman bagian per bagian masa berlakunya akan dihitung sejak tanggal Pengumuman bagian yang terakhir. isêpiSedangkan Ciptaan yang terdiri atas dua jilid atau lebih yang dilakukan Pengumuman secara berkala dan tidak bersamaan waktunya, maka masa berlakunya untuk setiap jilid dari Ciptaan tersebut dianggap sebagai Ciptaan tersendiri. 


\section{Musik Sampling sebagai Hak Cipta}

Dalam UU Hak Cipta, salah satu ciptaan yang dilindungi adalah lagu atau musik dengan atau tanpa teks. Seperti yang telah dijelaskan pada latar belakang, bahwa musik merupakan harmonisasi bunyi yang terbentuk dari adanya irama, melodi, dan vokal. Dengan adanya kriteria "dengan atau tanpa teks", maka lagu atau musik dapat diartikan secara luas, bahwa hak cipta terhadap lagu atau musik tidak terbatas pada lagu atau musik yang secara utuh, tapi juga bagian per bagian dalam sebuah lagu atau musik tersebut. Contohnya sebuah lagu yang diciptakan oleh sebuah band yang terdiri dari berbagai instrument musik yang berpadu dalam harmonisasi bunyi. Dari banyaknya instrumen musik yang ada dalam band tersebut, apabila dikaitkan dengan pengertian luas dari lagu atau musik, sehingga walaupun band tersebut memainkan lagu yang sama, setiap bunyi dari instrument musik tersebut memiliki hak cipta yang tersendiri. Hal ini berpengaruh dalam sampling. Menurut seorang Produser musik Rap, Daddy-O menyatakan bahwa "Sampling adalah sesuatu yang anda gabungkan bagian demi bagian dari apa yang orang lain telah buat. Ketika anda menyelesaikan produk tersebut, maka akan anda mendapatkan sesuatu yang baru". ${ }^{19}$ Dari pengertian tersebut maka pada proses sampling, sampler dapat mengambil bagian dari lagu atau musik yang sudah ada, misalnya mengambil ketukan dari pukulan senar drum atau melodi dari gitar yang nantinya akan diolah oleh sampler dengan kreativitasnya dan membentuk suatu komposisi dan lagu atau musik yang baru.

Sebagai salah satu bentuk karya yang dilindungi hak cipta, sebagaimana dijelaskan sebelumnya bahwa dalam ciptaan hak cipta dapat dikelompokkan dalam dua kelompok, yaitu ciptaan asli dan ciptaan turunan yang juga berpengaruh pada jangka waktu perlindungan hak cipta. Kemudian akan muncul pertanyaan berkaitan mengenai status ciptaan lagu atau musik yang merupakan hasil dari proses sampling merupakan ciptaan asli atau ciptaan turunan. Seperti dijelaskan sebelumnya, bahwa dalam hak cipta terdapat teori mengenai standar perlindungan

\footnotetext{
${ }^{19}$ John Lindenbaum, 'Music Sampling and Copyright Law'(Princeton University 1999).[2].
} 
hak cipta yaitu Originality, Creativity, dan Fixation yang berkaitan dengan apakah suatu ciptaan dianggap sebagai ciptaan asli atau ciptaan turunan. Walaupun dalam proses sampling menggunakan bagian dari hak cipta lagu atau musik orang lain, dalam melakukan pengolahan untuk membuat sebuah lagu atau musik yang baru sampler juga melakukan proses kreativitas selayaknya musisi pada umumnya. Hal ini dikarenakan proses sampling hanya mengambil sebagian kecil dari lagu atau musik yang sudah ada sehingga ketika proses sampling sudah dilakukan, bagian tersebut tidak bisa dikatakan sebagai sebuah ciptaan yang utuh dan dapat langsung dinikmati oleh masyarakat. Sampler perlu melakukan pengolahan terhadap hasil sampling yang dilakukannya dengan lagu atau musik yang dia ciptakan sendiri, sehingga akan terbentuk sebuah komposisi lagu atau musik baru yang dapat dinikmati dan disebarluaskan kepada masyarakat. Lagu atau musik hasil dari pengolahan sampling tersebut dapat dikatakan sebagai hasil kreativitas yang orisinil dari sampler yang dapat pula dilindungi dengan hak cipta sebagai ciptaan asli yang terpisah dari ciptaan asal dari sampling tersebut.

Agar sampler dapat menggunakan sampling tanpa melakukan pelanggaran hak cipta, maka sampler harus memperoleh izin dari pemegang hak cipta, yang dalam hal ini adalah pencipta. Permohonan izin kepada pencipta dilakukan ketika sampler melakukan sampling dengan mengambil bagian dari komposisi asli lagu atau musik dan melakukan rekaman ulang secara mandiri terhadap bagian tersebut atau apabila dalam sebuah penampilan langsung, sampler secara manual memainkan bagian dari komposisi asli lagu atau musik tersebut. Akan tetapi, hal itu akan berbeda ketika sampler tidak menggunakan cara manual dalam menggunakan sampling, namun melakukan proses sampling pada rekaman lagu atau musik yang sudah ada.

Dalam HKI, selain hak cipta dikenal pula hak lain yang dinamakan hak terkait. Menurut Steward dan Sandison, hak terkait senantiasa merupakan hak yang timbul dari ciptaan yang berasal dari pengalihwujudan suatu karya karena hak tersebut merupakan perwujudan dari ciptaan yang telah ada. ${ }^{20}$ Berdasarkan pengertian

${ }^{20}$ Elyta Ras, Hukum Hak Cipta Indonesia (PT Citra Aditya Bakti 2012).[71]. 
tersebut, hak terkait akan ada ketika terjadi perubahan wujud suatu karya menjadi karya dalam bentuk lain. Dalam hal ini yang dimaksud dengan perubahan wujud suatu karya adalah berubahnya komposisi lagu atau musik yang diciptakan oleh Pencipta yang awalnya hanya berupa notasi musik, menjadi suatu karya lain yaitu sebuah lagu atau musik yang ditampilkan oleh pelaku pertunjukan dan direkam oleh produser fonogram, sehingga lagu atau musik tersebut dapat dinikmati oleh masyarakat.

Dalam menciptakan sebuah rekaman lagu atau musik yang dapat dinikmati oleh masyarakat, tentunya diperlukan sebuah hubungan kerjasama antara pencipta sebagai pemegang hak cipta atas komposisi lagu atau musik dengan pelaku pertunjukan dan produser fonogram sebagai pemilik hak terkait. Di Indonesia, pelaku pertunjukan dalam dunia musik biasanya telah terikat kontrak pada perusahaan fonogram sehingga pelaku pertunjukan tersebut dapat melakukan rekaman dan mempertunjukkan lagu atau musik tersebut ke masyarakat yang akan diatur jadwalnya oleh perusahaan fonogram tempat pelaku pertunjukan tersebut dikontrak. Untuk memenuhi kontrak pelaku pertunjukan untuk melakukan rekaman dan memperoleh keuntungan ekonomi dari rekaman tersebut, maka perusahaan fonogram akan mencari pencipta lagu atau musik yang dapat bekerjasama untuk memberikan izin penggunaan karyanya atau tidak menutup kemungkinan pencipta tersebut yang menawarkan sendiri hasil karyanya melalui demo yang dia kirimkan kepada perusahaan fonogram.

Ketika terdapat kesepakatan dari pihak pencipta dan perusahaan fonogram dalam penggunaan komposisi lagu atau musik milik pencipta, maka para pihak tersebut dapat mengikatkan diri dalam perjanjian lisensi terhadap komposisi lagu atau musik milik pencipta. Setelah didapatkannya izin penggunaan komposisi tersebut, maka perusahaan fonogram dapat meminta pelaku pertunjukan yang terikat kontrak dengan perusahaan fonogram tersebut untuk dapat merekam dan mempertunjukan komposisi lagu atau musik tersebut dengan kemampuan yang dimilikinya, sehingga komposisi lagu atau musik yang semula hanya dapat dibaca dan dinikmati oleh pencipta dapat pula dinikmati oleh masyarakat dan dapat diperoleh keuntungan ekonomi yang akan dibagi oleh para pihak tersebut sesuai dengan perjanjiannya masing-masing. 
Sampler yang menggunakan cara digital dalam melakukan sampling merupakan pihak lain diluar hubungan hukum yang tercipta antara pencipta, produser fonogram, dan pelaku pertunjukan. Hal ini dikarenakan selain menggunakan bagian komposisi lagu atau musik yang merupakan hak cipta yang dimiliki pencipta, sampler juga menggunakan rekaman lagu atau musik yang merupakan produk hak terkait. Oleh karena itu, terkait dengan hak ekonomi yang dimiliki pelaku pertunjukan dan produser fonogram yang telah dijelaskan, maka seperti halnya Pencipta, ketika ada pihak lain yang dirasa telah merugikan hak ekonomi dari pemilik hak terkait, maka mereka memiliki hak untuk menggugat pihak lain yang melanggar hak terkait yang dimiliki pelaku pertunjukan dan produser fonogram. Oleh karena itu, ketika sampler melakukan proses sampling secara digital, maka selain memperoleh izin dari pencipta yang mempunyai hak cipta dari komposisi lagu atau musik, sampler juga perlu mendapatkan izin dari pemilik hak terkait dari rekaman lagu atau musik yang akan digunakan sebagai sampling.

\section{Perjanjian Lisensi dalam Penggunaan Musik Sampling}

Seperti telah penulis uraikan sebelumnya, bahwa untuk dapat menggunakan hak cipta orang lain dalam musik sampling, dibutuhkan izin kepada pemegang hak cipta dan hak terkait dari lagu atau musik yang akan digunakan. Dalam hak cipta, izin yang dilakukan oleh sampler berupa Lisensi. Lisensi sendiri berasal dari kata Latin "Licentia". ${ }^{21}$ Ketika pemberi lisensi (Licensor) memberikan lisensi kepada orang lain (Licensee), maka pemberi lisensi memberikan izin kepada pihak lain tersebut untuk menggunakan sesuatu yang sebelumnya tidak boleh digunakan, ${ }^{22}$ yang dalam hal ini adalah penggunaan hak cipta lagu atau musik terhadap musik sampling. Dalam UU Hak Cipta, pengertian lisensi dijelaskan pada Pasal 1 angka 20 yang menyatakan bahwa lisensi adalah izin tertulis yang diberikan oleh Pemegang Hak Cipta atau Pemilik Hak Terkait kepada pihak lain untuk melaksanakan hak ekonomi atas Ciptaannya atau produk Hak Terkait dengan syarat tertentu.

\footnotetext{
${ }^{21}$ Roeslan Saleh, Seluk Beluk Praktis Lisensi (Sinar Grafika 1991).[11].

${ }^{22}$ ibid.
} 
Lisensi sendiri dapat dibagi menjadi dua macam, yaitu lisensi wajib dan lisensi umum. Lisensi wajib adalah izin untuk melakukan penerjemahan dan/atau penggandaan ciptaan dalam bidang ilmu pengetahuan dan sastra yang diberikan berdasarkan keputusan Menteri atas dasar permohonan dengan tujuan untuk kepentingan pendidikan dan/atau ilmu pengetahuan serta kegiatan penelitian dan pengembangan. Sedangkan lisensi umum merupakan lisensi yang melibatkan suatu bentuk negosiasi untuk pemberian izin pemakaian hak kekayaan intelektual antara pemberi lisensi dan penerima lisensi. ${ }^{23}$ Pada lisensi wajib dan lisensi umum dapat berlaku dalam jangka waktu tertentu dan tidak melebihi jangka waktu perlindungan hak cipta dan hak terkait. Kemudian dalam lisensi umum penerima lisensi memiliki kewajiban untuk memberikan imbalan yang wajar kepada pemberi lisensi yang disebut juga sebagai royalti.

Izin yang diberikan oleh pemberi lisensi kepada penerima lisensi seperti yang dijelaskan sebelumnya kemudian dituangkan dalam bentuk perjanjian lisensi. Sebagai salah satu lingkup hukum perjanjian, dalam membuat perjanjian lisensi tentunya akan tunduk pada ketentuan mengenai perjanjian yang diatur dalam BW. Menurut ketentuan dalam buku III BW yang mengatur tentang perikatan, pengertian perjanjian menurut Pasal 1313 BW adalah suatu perbuatan dengan mana satu orang atau lebih mengikatkan dirinya terhadap orang lain atau lebih. Jadi syarat utama untuk adanya suatu perjanjian menurut Pasal 1313 BW adalah adanya para pihak dalam perjanjian yang terdiri dari dua orang atau lebih dan adanya suatu perbuatan hukum yang merupakan hubungan hukum, artinya melahirkan hak dan kewajiban antara para pihak yang melakukan perjanjian.

Agar sebuah perjanjian dianggap sah menurut hukum, maka harus memenuhi syarat-syarat yang diatur dalam Pasal 1320 BW yang menyebutkan bahwa terdapat empat syarat sahnya perjanjian, yaitu:

1. Sepakat mereka yang mengikatkan dirinya;

2. Kecakapan untuk membuat suatu perikatan;

3. Suatu hal tertentu;

4. Suatu sebab yang halal.

${ }^{23}$ Gunawan Widjaja, Lisensi (PT Raja Grafindo Persada 2003).[17]. 
Syarat sahnya perjanjian diatas dapat dikelompokkan dalam dua kelompok, yaitu syarat subyektif dan syarat objektif. Syarat subyektif adalah syarat mengenai subyek atau pihak yang membuat perjanjian tersebut, yaitu syarat mengenai kesepakatan dan kecakapan. ${ }^{24}$ Sedangkan syarat objektif adalah syarat mengenai perjanjian itu sendiri, yaitu syarat mengenai suatu hal tertentu dan suatu sebab yang halal. ${ }^{25}$ Dengan adanya pengelompokan mengenai syarat ini, maka ketika pada suatu perjanjian syarat-syarat tersebut tidak dipenuhi, maka akan menimbulkan konsekuensi yang berbeda.

Konsekuensi dari tidak terpenuhinya syarat subyektif dalam suatu perjanjian adalah dapat dibatalkannya perjanjian tersebut. ${ }^{26}$ Dapat dibatalkan dalam hal ini pihak yang berkepentingan yaitu pihak yang tidak cakap atau pihak yang memberikan kesepakatannya secara tidak bebas dapat meminta pembatalan perjanjian tersebut ke pengadilan. Apabila dalam perjanjian pihak tersebut tidak meminta pembatalan perjanjian, maka perjanjian tersebut akan masih memiliki kekuatan mengikat karena belum ada putusan pengadilan yang memutuskan bahwa perjanjian tersebut batal. Sedangkan apabila suatu perjanjian tidak memenuhi syarat obyektif, maka perjanjian tersebut akan batal demi hukum, maksudnya adalah sejak awal dianggap tidak pernah lahir perjanjian dan tidak pernah ada perikatan diantara para pihak. ${ }^{27}$ Setelah ke-4 syarat sahnya perjanjian telah terpenuhi, maka perjanjian tersebut akan sah secara hukum dan mengikat para pihak yang menyetujuinya.

Secara umum, pengaturan mengenai perjanjian diatur dalam BW. BW tidak memberikan secara sistematis mengenai bentuk dari perjanjian, akan tetapi bila ditelaah berdasarkan ketentuan dalam BW dapat disimpulkan bahwa dalam BW terdapat dua bentuk perjanjian, yaitu perjanjian lisan dan perjanjian tertulis. Perjanjian lisan adalah perjanjian yang yang dibuat oleh para pihak cukup secara lisan atau dengan kesepakatan. ${ }^{28}$ Sedangkan perjanjian tertulis adalah perjanjian

\footnotetext{
${ }^{24}$ Subekti, Aneka Perjanjian (PT Citra Aditya Bakti 1995).[17].

${ }^{25}$ ibid.

${ }^{26}$ ibid. [20].

${ }^{27}$ ibid.

${ }^{28}$ Salim SH, Hukum Kontrak: Teori dan Teknik Penyusunan Kontrak (Sinar Grafika 2010).[28].
} 
yang dibuat oleh para pihak dalam bentuk tulisan. Perjanjian tertulis sendiri dibagi dalam dua bentuk, yaitu Akta Otentik dan Akta di Bawah Tangan. Berdasarkan Pasal 1868 BW, Akta Otentik adalah suatu akta yang didalam bentuk yang ditentukan oleh undang-undang, dibuat oleh atau dihadapan pegawai umum yang berkuasa untuk itu ditempat akta dibuat. Sedangkan Akta di Bawah Tangan diatur dalam Pasal 1874 BW, yaitu tulisan atau akta yang dibuat tanpa perantara pegawai umum, tetapi dibuat sendiri oleh seseorang atau para pihak. ${ }^{29}$

Berdasarkan Pasal 80 ayat (1) UU Hak Cipta yang menyatakan bahwa pemegang Hak Cipta dan/atau pemilik Hak Terkait memiliki hak untuk memberikan Lisensi kepada pihak lain berdasarkan perjanjian tertulis untuk melaksanakan perbuatan yang berkaitan dengan hak ekonomi yang dimiliki oleh pemegang Hak Cipta dan/atau pemilik Hak Terkait. Perjanjian tertulis yang dimaksud baik dalam pengertian lisensi dalam Pasal 1 angka 20 dan Pasal 80 ayat (1) UU Hak Cipta ini tidak dijelaskan lebih lanjut, sehingga bila dikaitkan dengan bentuk perjanjian yang telah dijelaskan, maka dapat ditarik kesimpulan bahwa perjanjian lisensi dapat dibuat dalam bentuk perjanjian tertulis baik dalam bentuk akta otentik yang dibuat di hadapan pejabat umum maupun akta di bawah tangan.

Membuat akta otentik merupakan salah satu kewenangan notaris sebagai pejabat umum berdasarkan Pasal 15 ayat (1) Undang-Undang Nomor 2 tahun 2014 tentang Perubahan atas Undang-Undang Nomor 30 tahun 2004 tentang Jabatan Notaris (selanjutnya akan disebut sebagai UUJN). Bentuk dari akta otentik tersebut telah ditetapkan oleh UUJN, dimana setiap akta yang dibuat oleh notaris harus terdiri dari :

1. awal akta atau kepala akta;

2. badan akta; dan

3. akhir atau penutup akta.

Sebagai salah satu dari alat bukti surat, akta otentik yang dibuat oleh pejabat umum yang dalam hal ini adalah notaris memiliki nilai kekuatan pembuktian yang

\footnotetext{
${ }^{29}$ Yahya Harahap, Hukum Acara Perdata (Sinar Grafika 2013).[589].
} 
sempurna (volledig bewijskracht) dan mengikat (bindende bewijskracht). ${ }^{30} \mathrm{Hal}$ ini berbeda dengan Akta di bawah tangan yang tidak dibuat oleh notaris, melainkan oleh para pihak atau bahkan dibuat oleh salah satu pihak saja dalam suatu perjanjian lisensi. Berdasarkan Pasal 1875-1877 BW, dijelaskan bahwa apabila para pihak secara tegas mengakui tandatangan dalam akta di bawah tangan tersebut, maka akta tersebut memiliki nilai kekuatan pembuktian yang sempurna seperti akta otentik, akan tetapi apabila ada pihak yang memungkiri tulisan atau tanda tangannya dalam akta tersebut, maka nilai kekuatan pembuktiannya menjadi bukti permulaan tulisan saja. ${ }^{31}$

Sistem yang dianut dalam Buku III BW adalah sistem terbuka, dimana para pihak dalam perikatan dapat menyampingkan peraturan-peraturan yang diatur dalam Bab III dengan syarat tidak melanggar ketentuan undang-undang dan ketertiban umum. ${ }^{32}$ Dengan kata lain, peraturan-peraturan dalam Bab III BW, pada umumnya hanya merupakan hukum pelengkap, bukan hukum yang keras dan memaksa. ${ }^{33}$ Akan tetapi, walaupun sistem terbuka dalam Bab III BW memberikan keleluasaan bagi para pihak dalam membuat perjanjian, keleluasaan tersebut tidak berarti para pihak dapat membuat perjanjian dengan sembarangan tanpa memperhatikan bentuk dari suatu perjanjian lisensi penggunaan musik sampling. Dalam membuat sebuah perjanjian lisensi penggunaan sampling, perlu diperhatikan pula mengenai anatomi dasar dari perjanjian. Secara umum terdapat enam hal yang perlu dituliskan dalam sebuah perjanjian, yaitu: ${ }^{34}$

\section{Judul perjanjian}

Pada awal perjanjian, para pihak dapat memberikan judul yang sesuai dengan perjanjian yang akan dibuat, misalnya: "Perjanjian Lisensi Penggunaan musik Sampling”. Penulisan judul perjanjian ini dilakukan untuk mempermudah para pihak dalam membedakan perjanjian yang dibuat dengan dokumen-dokumen

\footnotetext{
${ }^{30}$ ibid. [545].

${ }^{31}$ ibid., [603].

${ }^{32}$ Subekti, Pokok-Pokok dalam Hukum Perdata (PT Intermasa 1985).[128].

${ }^{33}$ ibid.

${ }^{34}$ Rini Pamungkasih, 101 Draft Surat Perjanjian (Kontrak) (Gradien Mediatama 2009).[21].
} 
lainnya yang mungkin dimiliki oleh para pihak. Penempatan judul perjanjian ini sebaiknya diletakkan ditengah atas perjanjian dengan disertai nomor dokumen dibawah judul yang berfungsi untuk mempermudah administrasi perjanjian.

\section{Pembukaan}

Pada bagian ini, para pihak yang dapat menuliskan mengenai hari, tanggal, dan tempat pembuatan perjanjian dan penandatangan perjanjian lisensi penggunaan sampling tersebut. Akan tetapi seringkali pada pembukaan dalam perjanjian hanya ditulis secara singkat yaitu dengan menggunakan "Yang bertanda tangan di bawah ini". ${ }^{35}$

\section{Komparasi}

Pada bagian ini dituliskan secara jelas dan rinci mengenai identitas para pihak yang melakukan perjanjian lisensi, seperti:

a. Penulisan identitas diri dari Pihak pemberi lisensi dan pihak penerima lisensi secara lengkap sesuai dengan Kartu Tanda Penduduk. Apabila pihak dalam perjanjian tersebut adalah badan usaha maka dapat disebutkan pula tempat kedudukannya berdasarkan akta pendirian badan hukum.

b. Pihak pemberi lisensi penggunaan sampling dapat berupa perorangan maupun badan hukum. Apabila pemberi lisensi adalah sebuah badan hukum seperti perusahaan fonogram, maka harus dijelaskan siapa yang berwenang mewakili dan melakukan tindakan hukum dengan disertai dasar kewenangannya untuk mewakili badan hukum tersebut, misalnya berupa surat kuasa dari perusahaan.

c. Kedudukan para pihak dalam perjanjian lisensi tersebut, misalnya pihak pemberi lisensi sebagai pihak I dan pihak penerima lisensi sebagai pihak II dalam perjanjian lisensi.

4. Recital

Bagian recital adalah penjelasan resmi atau latar belakang atas suatu keadaan dalam suatu perjanjian untuk menjelaskan mengapa terjadi perikatan. ${ }^{36}$ Dengan dijelaskannya alasan-alasan pembuatan perjanjian tersebut secara singkat, maka akan dapat diketahui maksud dan tujuan dari dibentuknya perjanjian lisensi

\footnotetext{
${ }^{35}$ ibid.

${ }^{36}$ Hasanuddin Rahman, Contract Drafting (PT Citra Aditya Bakti 2006).[120].
} 
penggunaan musik sampling yang dibuat oleh para pihak.

5. Isi perjanjian

Bagian ini merupakan isi pasal-pasal yang mengatur keinginan, hak-hak, kewajiban-kewajiban, dan ketentuan-ketentuan lain yang disepakati oleh para pihak. Dalam merumuskan pasal-pasal yang baik dalam sebuah perjanjian lisensi penggunaan sampling, maka harus memenuhi beberapa syarat, yaitu $:^{37}$

a. Urutan, bahwa dalam merumuskan pasal-pasal dalam sebuah perjanjian lisensi harus mencerminkan kronologis dari perjanjian itu sendiri. Hal ini penting agar dapat mempermudah para pihak dalam mempelajari dan mengetahui halhal yang diatur dalam setiap pasal yang dirumuskan dalam perjanjian tersebut.

b. Ketegasan, artinya dalam merumuskan pasal-pasal dalam sebuah perjanjian lisensi, diperlukan pemilihan kalimat yang tegas tetapi mudah untuk dimengerti para pihak sehingga tidak menimbulkan penafsiran ganda.

c. Keterpaduan, artinya antara satu ayat dengan ayat lainnya dalam suatu pasal harus berhubungan satu sama lain.

d. Kesatuan, artinya dalam satu pasal harus mencerminkan satu kondisi, akan tetapi antara satu pasal dengan pasal lain harus saling mendukung.

e. Kelengkapan, artinya karena dalam satu pasal harus mencerminkan satu kondisi, maka informasi dalam pasal-pasal tersebut harus lengkap.

6. Penutup

Pada bagian penutup ini disebutkan tempat dan tanggal ditandatanganinya perjanjian lisensi penggunaan sampling serta tanda tangan para pihak sebagai bukti kesepakatan para pihak terhadap isi perjanjian tersebut.

Berdasarkan Pasal-Pasal dalam UU Hak Cipta, dapat disimpulkan bahwa dalam pembuatan perjanjian lisensi dalam penggunaan musik sampling, sekurangkurangnya memuat klausula-klausula tentang:

a. Objek perjanjian lisensi secara rinci, yang dalam hal ini adalah bagian dari lagu yang akan digunakan sebagai musik sampling secara spesifik;

b. Jangka waktu perjanjian lisensi;

c. Perpanjangan jangka waktu perjanjian lisensi dengan melihat ketentuan apakah objek perjanjian belum melebihi jangka waktu perlindungan Hak Cipta dan Hak terkait;

d. Pelaksanaan lisensi untuk seluruh atau sebagian dari hak eksklusif;

e. Royalti dan cara pembayarannya;

f. Dapat atau tidaknya penerima lisensi memberikan lisensi lebih lanjut kepada

${ }^{37}$ ibid., [122]. 
pihak ketiga;

g. Penyelesaian sengketa.

Ketika perjanjian lisensi dalam penggunaan musik sampling telah selesai dibuat, perjanjian lisensi tersebut kemudian harus dilakukan pendaftaran ke Menteri untuk dicatat dalam daftar umum perjanjian Lisensi Hak Cipta dengan dikenai biaya. Pencatatan ini dilakukan agar perjanjian lisensi yang telah dicatatkan dapat memiliki akibat hukum kepada pihak ketiga. Mengenai syarat dan ketentuan pencatatan perjanjian lisensi diatur berdasarkan Peraturan Menteri Hukum dan Hak Asasi Manusia Republik Indonesia Nomor 8 tahun 2016 tentang syarat dan tata cara permohonan pencatatan perjanjian lisensi kekayaan intelektual. Berdasarkan Permenkumham tersebut, pencatatan perjanjian lisensi dapat dilakukan secara elektronik yang dilakukan melalui halaman resmi Direktorat Jenderal Kekayaan Intelektual atau secara nonelektronik dengan pengajuan secara tertulis kepada Menteri.

\section{Kesimpulan}

Hasil dari penggunaan Sampling merupakan salah satu ciptaan musikyang dapat dilindungi oleh hak cipta sebagai ciptaan asli. Dalam penggunaan musik sampling, apabila sampler menggunakan cara manual maka sampler hanya memerlukan izin dari pencipta atau pemegang hak cipta dari komposisi lagu atau musik asal. Akan tetapi apabila sampler menggunakan cara digital yang menggunakan rekaman lagu atau musik, maka selain memerlukan izin dari penggunaan komposisi lagu atau musik, sampler juga memerlukan izin dari pemilik produk hak terkait, yang dalam hal ini adalah pelaku pertunjukan dan produser fonogram.

Perjanjian lisensi penggunaan musik sampling merupakan salah satu bentuk perjanjian dalam bentuk tertulis yang dapat dibuat baik dalam bentuk akta otentik yang dibuat oleh notaris atau akta di bawah tangan. Dalam membuat perjanjian lisensi yang dapat mengikat para pihak yang membuatnya, maka harus dipenuhi syarat sahnya perjanjian seperti yang telah diatur dalam Pasal 1320 BW. Berdasarkan sistem terbuka yang dianut Buku III BW, maka dalam membuat perjanjian lisensi penggunaan sampling, para pihak dapat dengan bebas menentukan sendiri isi dari perjanjian lisensi penggunaan sampling sesuai dengan kesepakatan para pihak, 
akan tetapi dalam melakukan perancangan perjanjian lisensi perlu memperhatikan juga anatomi dasar dari perjanjian, yaitu judul perjanjian, pembukaan, komparasi, recital, isi perjanjian, dan penutup. Setelah perjanjian lisensi penggunaan musik sampling selesai dibuat, maka perjanjian tersebut perlu didaftarkan sehingga dapat memiliki akibat hukum bagi pihak ketiga.

\section{Daftar Bacaan}

\section{Buku}

Elyta Ras, Hukum Hak Cipta Indonesia (PT Citra Aditya Bakti 2012).

Gunawan Widjaja, Lisensi (PT Raja Grafindo Persada 2003).

Hasanuddin Rahman, Contract Drafting (PT Citra Aditya Bakti 2006).

Peter Mahmud Marzuki, Penelitian Hukum (Prenadamedia Group 2011).

Rahmi Jened, Interface Hukum Kekayaan Intelektual dan Hukum Persaingan (Penyalahgunaan HKI) (Rajawali Press 2013).

Rini Pamungkasih, 101 Draft Surat Perjanjian (Kontrak) (Gradien Mediatama 2009).

Roeslan Saleh, Seluk Beluk Praktis Lisensi (Sinar Grafika 1991).

Salim SH, Hukum Kontrak: Teori dan Teknik Penyusunan Kontrak (Sinar Grafika 2010).

Simon Stokes, Art \& Copyright (Hart Publishing 2001).

Subekti, Aneka Perjanjian (PT Citra Aditya Bakti 1995).

Subekti, Pokok-Pokok dalam Hukum Perdata (PT Intermasa 1985).

Yahya Harahap, Hukum Acara Perdata (Sinar Grafika 2013).

\section{Jurnal}

Brian Fitzgerald dan Damien O'brien, 'Digital Sampling And Culture Jamming In A Remix World: What Does The Law Allow?', (2005), 10(4) Media and Arts Law Review. 
Henry Self, 'Digital Sampling (A Cultural Perpective)', (2002), 9:2 UCLA Entertainment Law Review.

\section{Thesis}

John Lindenbaum, 'Music Sampling and Copyright Law' (Princeton University 1999).

\section{Peraturan Perundang-undangan}

Undang-Undang Nomor 30 tahun 2004 tentang Jabatan Notaris (Lembaran Negara Republik Indonesia tahun 2004 Nomor 117, Tambahan Lembaran Negara Republik Indonesia Nomor 4432).

Undang-Undang Nomor 2 tahun 2014 tentang Perubahan Undang-Undang Nomor 30 tahun 2004 tentang Jabatan Notaris (Lembaran Negara Republik Indonesia tahun 2014 Nomor 3, Tambahan Lembaran Negara Republik Indonesia Nomor 5491).

Undang-Undang Nomor 28 tahun 2014 tentang Hak Cipta (Lembaran Negara Republik Indonesia tahun 2014 nomor 266, Tambahan Lembaran Negara Republik Indonesia nomor 5599).

Peraturan Menteri Hukum dan Hak Asasi Manusia Nomor 8 tahun 2016 tentang Syarat dan Tata Cara Permohonan Pencatatan Perjanjian Lisensi Kekayaan Intelektual (Berita Negara Republik Indonesia tahun 2016 nomor 301).

Kitab Undang-Undang Hukum Perdata.

Berne Convention for the Protection of Literary and Artistic Works, 1971. 
--Halaman ini sengaja dibiarkan kosong-- 